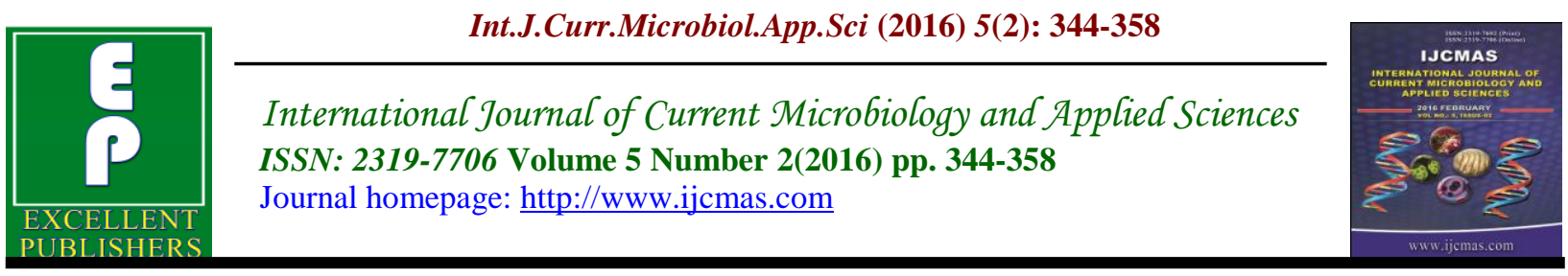

Original Research Article

doi: http://dx.doi.org/10.20546/ijcmas.2016.502.040

\title{
Prevalence of Keratinolytic Fungi Isolated from the Poultry waste sites around Shivamogga City, Karnataka, India
}

\author{
R. Ashwathanarayana* and Raja naika \\ Department of PG studies and Research in Applied Botany, Jnanasahyadri, Kuvempu University, \\ Shankaraghatta, Shivamogga, Karnataka, India- 577451 \\ *Corresponding author
}

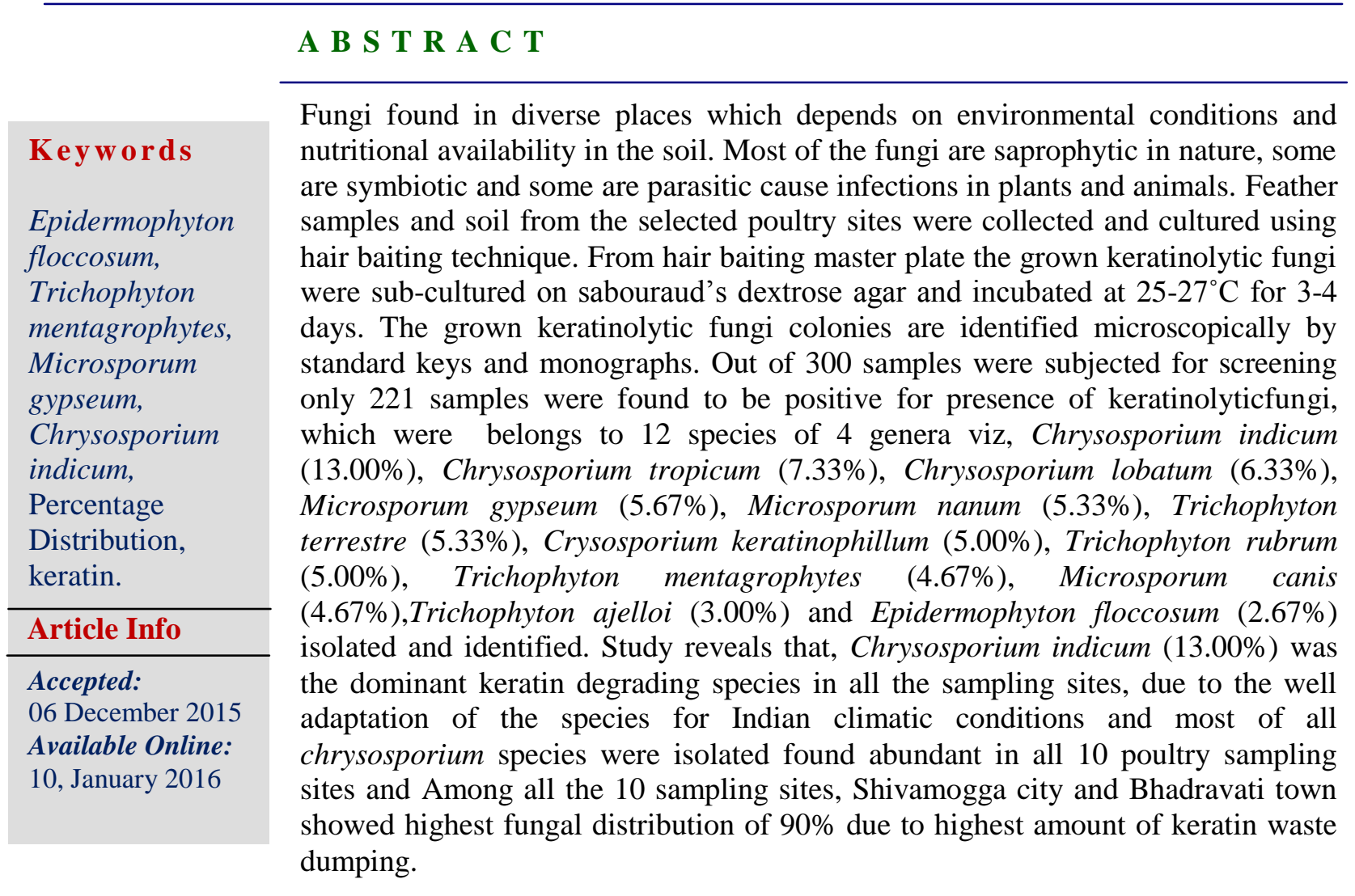

\section{Introduction}

Keratinolytic fungi is a group of fungi, found to be ecologically and environmentally important because, they recycles one of the most abundant and highly stable animal protein on earth called "keratin" (Deshmukh S. K and Verekar S.
A. 2006) Keratin is a scleroprotein, which is hard to degrade and chemically unreactive, has numerous cross-links of disulfide bonds, which provides additional strength to the structure, due to this, only few organisms will use this as energy source. In the 
Kingdom Eumycota (true fungi), two groups - the Deuteromycetes and the Ascomycetes - which have keratinolytic members that are commonly occur in soil as keratin decomposers. Within these groups some species are potential pathogens and some are opportunistic, can cause infections to the mammals, particularly on the skin and scalp called as Dermatophytes. (Sharma R and Rajak RC, 2003).

Keratinolytic fungi were classified into three ecological groups depending on their habitat preference; they are soil loving Geophilic, animal loving Zoophilic and human loving Anthropophilic. (Sharma and Swati. 2012)

Majchrowicz \& Dominik (1969) gives a modified definition to differentiate keratinolytic fungi from keratinophilic fungi, In which keratinolytic fungi are able to attack and completely degrade keratin, whereas keratinophilic fungi associates keratinolytic fungi, utilizing only nonkeratinous components of keratinous substrata or the products of keratin decomposition.

The prevalence of keratinolytic fungi was mainly relied on the factors, like presence of energy resource (keratin), soil $\mathrm{pH}$, humidity, temperature, geographical location.

(Deshmukh S. K and Verekar S. A. 2006).The optimum $\mathrm{pH}$ for the growth of keratinolytic fungi was 9 and growth of these fungi was inhibited at $\mathrm{pH}$ below 4.5. (Ziegler 1966).

Keratin substances found in the soil or on its surface are not only an important substrate for keratinolytic fungi, but also a specific environment that allows them to survive and defend themselves against other competitive saprotrophic microorganisms (Garetta and Piontelli 1975).
In commercial poultry processing plants, feathers are the main waste, which account for $5 \sim 7 \%$ of the total weight of mature chickens. Every year more than 20,000 tons of feather is being produced as waste by poultry farming (Vogt and Stute, 1975).Worldwide, around 8.5 billion tons of poultry waste is generated annually, of which, India's contribution alone is 350 million tons. The poultry feathers are either dumped, which pollute the soil or which again pollutes the air while burning. (Saha S. 2013).

During the past years many research work has been done on keratinolytic fungi and dermatophytes in countries like Sweden (Pàlsson G. 1968), Iraq (Abdullah S.K and. Hassan D.A. 1995), Papua New Guinea (Marchisio V.F et al, 1991), Italy (Papini R et al, 1998), Ukraine (Volz P.A et al,1991), Islamic Republic of Iran (Hedayati M T and Mirzakhani M. 2009, Moallaei H et al, 2006, Kachuei R et al, 2012, Pakshir K and Hashemi J. 2006), Italy (Marchisio V.F et al, 1996), Poland (Spiewak $\mathrm{R}$ and Szostak W. 2000) Switzerland (Monod M et al, 2002) Korea (Kim J D. 2003) etc.

In India considerable research work has been done on keratinolytic fungi and dermatophytes and many researchers were successful in isolation and culturing of keratinolytic fungi from the soil in several regions viz., Jaipur (Sharma, M and Sharma M. 2010), Mount abu (Garg, 1966), Mussoorie (Deshmukh and Agarwal, 1985), Mumbai (Deshmukh, 1999, 2004), chilkalake (Ghosh and Bhatt, 2000) and Mysore (Deshmukh etal, 2000), Damoh (Khanam and Jain, 2002), Kerala (Deshmukh, 2002). Jharkhand(Kumar, 2013) etc.

Keratinophilic fungi were found to be present in the environment with variable distribution patterns that depend on different 
factors, such as human and or animal presence, which are of fundamental importance to confirm the present findings. Reports are available on the presence of these fungi in different soil habitats from different countries e g., Egypt, Australia, Palestine, Spain, Kuwait, Ukraine and Malaysia, which have indicated that, this group of fungi are distributed worldwide (Anbu et al., 2004).

Current study targeted on the distribution of keratinolytic fungi in the selected poultry waste sites around Shivamogga city, Karnataka. India.

\section{Materials and Methods}

\section{Characterization of Sampling Site}

Samples were collected from 10 identified sites around Shivamogga, Karnataka, India. Shivamogga is one of the district headquarters of Karnataka state and the city is situated on the bank of Tunga river at $13^{\circ} 56^{\prime} \mathrm{N} 75^{\circ} 34^{\prime} \mathrm{E}$.

The soil type is varies from laterite clay soil to red gravelly loam and red loamy soil, the climate is tropical wet and dry, summer, with an average temperature of $20-35^{\circ} \mathrm{C}(68$ $-95^{\circ} \mathrm{F}$ ) winter and early part of summer are dry period in this region and most of the part is covered with Western Ghats, one of the biological hotspots in the world and also known for plentiful rainfall and thick evergreen forest.

\section{Sample Collection}

The feather and soil samples were collected in the monthly interval (superficial soil from 5- 15 inches depth) from dumping yard of poultry waste sites, with the sterile plastic spoon and the feather samples were collected with the sterile nylon broom, collected in a polypropylene bags.

\section{Incubation}

The feather samples were incubated on the soil sample by using hair baiting technique suggested by Vanbreuseghem (1952). The feather samples were rinse with the sterile double distilled water, dried in shade, cut in to small pieces and sterilized by autoclaving at $120^{\circ} \mathrm{C}$ for 15 minutes. Approximately $50 \mathrm{~g}$ of each soil sample was placed in a sterile petri plate and baited with the weighed cut pieces of dry feather sample. Each plate was wetted with sterile distilled water periodically and incubated at room temperature for about 5 weeks. The fungal colonies grown on the feather samples were sub-cultured on sabouraud's agar media containing chloramphenicol and cyclohexamide and incubated at $25-27^{\circ} \mathrm{C}$.

\section{Identification and Characterization}

The identification of individual fungus was done on the basis of spore morphology, cultural characteristic and pigment formation on the reverse of slant (Forbes et al., 2002) and identification of keratinolytic fungi were microscopically done using standard keys and monographs suggested by Rippon, (1988); Rebell, (1974); Frey et al., (1979); Van Oorshot (1980); Cano and Gurrao (1990); Refai et al (2013); http://www.provlab.ab.ca/mycol/tutorials/de $\mathrm{rm} /$ dermwho.htmand also Mycosis manual was followed for the identification of isolated of kertinophilic fungi.(Table -1 and Table -2)

\section{Percentage of Distribution}

The percentage distribution was calculated by using the following formula.

\footnotetext{
Percentage of Distribution $=$ $\frac{\text { Total number of indivudual positive sample }}{\text { Total number of samples examined }} \times 100$ (Deshmukh SK and Verekar SA. 2006)
} 


\section{Results and Discussion}

The following fungal spices were isolated from different sites of soil samples collected around Shimoga city.12 species keratinolytic fungi were successfully isolated and identified, belongs to 4 genera. (Table-1)

Epidermophyton floccosum, Trichophyton ajelloi, Trichophyton rubrum, Trichophyton terrestre, Trichophyton mentagrophytes, Microsporum canis, Microsporum nanum, Microsporum gypseum, Chrysosporium tropicum, Chrysosporium indicum, Chrysosporium lobatum, Chrysosporium keratirophilum.

Isolation of keratinophilic fungi is carried out by hair-baiting technique (Vanbreuseghem, 1952). It is found that, keratinophilic fungi baits were appeared in 8 days in the plates of soil samples collected from slum area. Normally colonies will appear on hair baits in 25 to 45 days. Early appearance of colonies of keratinophilic fungi is due to, the adequate amount keratinoceous substance present in the soils and the growth stages of the keratinophilic fungi, which exists in the soil.

The colony characters of individual keratinolytic fungi with their habitat was described below.

\section{Epidermophyton floccosum}

On Sabouraud's dextrose agar colonies are usually slow growing, greenish-brown or khaki colored with a suede-like surface, raised and folded in the centre, with a flat periphery and submerged fringe of growth. Older cultures may develop white pleomorphic tufts of mycelium. A deep yellowish-brown reverse pigment is usually present. Microscopic morphology shows characteristic smooth, thin-walled macroconidia which are often produced in clusters growing directly from the hyphae. Numerous chlamydoconidia are formed in older cultures. No microconidia are formed.

\section{Trichophyton ajelloi}

Colonies are usually flat, powdery, and cream-tan to orange-tan in colour, with a blackish-purple submerged fringe and reverse. Macroconidia are numerous, smooth, thick-walled, elongate, cigar-shaped and multiseptate. Microconidia are usually absent.

\section{Trichophyton rubrum}

The growth rate of Trichophyton colonies in the lab can be slow to rather quick. Their texture is waxy, smooth and even to cottony. From the top, the color is white to bright yellowish beige or red violet. Reverse is pale, yellowish, brown, or reddish-brown.

\section{Trichophyton terrestre}

On Sabouraud's dextrose agar, colonies are usually flat to downy with a suede-like to granular texture resembling Trichophyton mentagrophytes. The surface colour may range from white to cream, buff to yellow, or greenish-yellow. Reverse pigmentation is usually yellowish-brown although some variants have a deep rose red reverse. Microconidia are large, clavate or pedicellate, usually exhibiting transition forms to more or less abundant lateral macroconidia. Macroconidia are clavate to cylindrical with rounded ends, smooth and thin-walled. Chlamydoconidia, hyphal spirals, racquet mycelium and antler hyphae may also be present.

\section{Trichophyton mentagrophytes}

On Sabouraud's dextrose agar, colonies are generally flat, white to cream in color, with 
a powdery to granular surface. Some cultures show central folding or develop raised central tufts or pleomorphic suedelike to downy areas. Reverse pigmentation is usually a yellow-brown to reddish-brown colour. Numerous single-celled micro conidia are formed, often in dense clusters. Microconidia are hyaline, smooth-walled, and are predominantly spherical to subspherical in shape; however occasional clavate to pyriform forms may occur. Varying numbers of spherical chlamydoconidia, spiral hyphae and smooth, thin-walled, clavate shaped, multicelled macroconidia may also be present.

\section{Microsporum canis}

In fluoresce a bright greenish-yellow under ultra-violet light. Colonies are flat, spreading, and white to cream-colored, with a dense cottony surface which may show some radial grooves. Colonies usually have a bright golden yellow to brownish yellow reverse pigment, but non-pigmented strains may also occur. Macroconidia are typically spindle-shaped, verrucose, thick-walled and often have a terminal knob, a few pyriform to clavate microconidia are also present. Macroconidia and microconidia are often not produced on primary isolation media and it is recommended that sub-cultures be made onto Lactritmel Agar and boiled polished rice grains to stimulate sporulation.

\section{Microsporum nanum}

They do not fluoresce under Wood's ultraviolet light. Colonies are flat, cream to buff in colour with a suede-like to powdery surface texture. Young colonies have a brownish-orange pigment which deepens into a dark reddish-brown with age. Cultures produce numerous small ovoid to pyriform, macroconidia are relatively thin, and finely echinulate (rough) walls and broad truncate bases. Many macroconidia are borne on conidiophores (stalks) which do not stain readily. Occasional clavate microconidia are present, which distinguishes $M$. nanum from some species of Chrysosporium.

\section{Microsporum gypseum}

They do not fluoresce under Wood's ultraviolet light. On Sabouraud's dextrose agar, colonies are usually flat, spreading, suedelike to granular, with a deep cream to tawnybuff to pale cinnamon coloured red surface. Many cultures develop a central white downy umbo (dome) or a fluffy white tuft of mycelium and some also have a narrow white peripheral boarder. A yellow-brown pigment, often with a central darker brown spot, is usually produced on the reverse; however a reddish-brown reverse pigment may be present in some strains. Cultures produce abundant, symmetrical, ellipsoidal, thin-walled, verrucose, 4-6 celled macroconidia. The terminal or distal ends of most macroconidia are slightly rounded, while the proximal ends (point of attachment to hyphae) are truncate. Numerous clavate shaped microconidia are also present, but these are not diagnostic.

\section{Chrysosporium tropicum}

Colonies are moderately fast growing, flat; white to tan to beige in colour, often with a powdery or granular surface texture. Reverse pigment absent or pale brownishyellow with age. Hyaline, one-celled (ameroconidia) are produced directly on vegetative hyphae by non-specialized conidiogenous cells. Conidia are typically pyriform to clavate with truncate bases and are formed either intercalary (arthroconidia), laterally (often on pedicels) or terminally. No macroconidia or hyphal spirals are seen (McGinnis 1980). 


\section{Chrysosporium lobatum}

It is a deuteromycetous fungus belonging to the order Moniliales and the family Moniliaceae. Initially, colonies were white and then became pale gray with a powdery form. Conidia are typically pyriform to clavate with truncate bases and are formed either intercalary, laterally (often on pedicels). No macroconidia or hyphal spirals are seen. Terminal and lateral conidia developed simultaneously and were sessile.

\section{Chrysosporium indicum}

The colonies are cream to white in colour, conidia are smooth or slightly echinulate, thin walled, mycelia are hyaline. Conidia are typically clavate with truncate bases and are formed either intercalary (arthroconidia), laterally (often on pedicels) or terminally. No macroconidia or hyphal spirals are seen

\section{Chrysosporium keratirophilum}

Colonies are moderately fast growing, flat, white to tan white in colour, they often with a powdery or granular surface texture. Hyaline, one-celled (ameroconidia) are produced directly on vegetative hyphae by non-specialized conidiogenous cells. Conidia are typically pyriform to clavate with truncate bases and are formed either intercalary (arthroconidia), laterally (often on pedicels), or terminally (Allender, 2011).

\section{Percentage distribution of all keratinolytic fungi among the sampling sites}

Samples were collected from 10 identified sampling sites around Shivamogga viz., Bhadravati, Soraba, Gajanuru, Mattur, Sagar, Shivamogga city, Shikaripura, Hosanagara, Thirthahalli and Holehonnuru.

Among all the 10 sampling sites, Shivamogga city and Bhadravati town showed highest fungal distribution of $90 \%$ due to highest amount of keratin waste dumping, followed by Sagar $80 \%$. (Table 3)

Hosanagara (76.67\%), Gajanuru (70\%), Shikaripura (70\%), Holehonnuru (70\%), Mattur (66.67\%), Soraba (63.33\%), showed moderate fungal distribution. (Graph -1)

Thirthahalli (60\%) showed least distribution this may be due to highly wet environmental condition, some keratinolytic fungi usually do not prefer high wet and cold condition. Human population also directly influence the distribution of keratinolytic fungi which mainly depend on keratin as an energy source.

Most of the keratinolytic fungi were showed above average distribution in all sampling poultry stations, which indicates that, the poultry sampling station were the main sources of keratinolytic fungi due to the abundant availability of keratin sources.

Heavy rainfall leaches base cation from the soil, increasing the percentage of $\mathrm{Al}^{3+}$ and $\mathrm{H}^{+}$comparative to other cations. Moreover, rainwater has a slightly acidic $\mathrm{pH}$ of 5.7 due to a reaction with $\mathrm{CO}_{2}$ in the atmosphere it forms carbonic acid (Sparks, 2003). So that in higher rainfall region Thirthahalli $(60 \%)$ we got least distribution of allkeratinolytic fungi.

On the other hand the amount of acidity also increased by agricultural activities. Use of fertilizers which contains ammonium $\left(\mathrm{NH}_{4}{ }^{+}\right)$ in the agricultural fields, reacts in the soil in a process called nitrification to form nitrate $\left(\mathrm{NO}_{3}{ }^{-}\right)$. This process release $\mathrm{H}+$ ions, in turn increases pH of the soil (Ziegler 1966) so, in Hosanagara, Shikaripura, Soraba, Holehonnuru sampling stations due to higher agricultural activities and utilization of more fertilizers (http://www.shimoga.nic. in/stats.htm) showed moderate fungal distribution for all keratinolytic fungi. 
Table.1 Anamorph Genera with Identified Species of Keratinolytic Fungi Isolated from Poultry Sites around Shivamogga

\begin{tabular}{|c|}
\hline Chrysosporium Corda 1833 \\
\hline C. keratinophilum (Frey) Carmichal (anam. A. fulvescens) \\
\hline C. tropicum Carmichal (anam.) \\
\hline C. lobatum (Scharapov) 1978 \\
\hline C. indicum (H.S. Randhawa \& R.S. Sandhu) Garg, 1966 \\
\hline EpidermophytonSabouraud 1907 \\
\hline E. floccosum (Harz) Langeron et Milochevitch 1930 \\
\hline Microsporum Gruby 1843 \\
\hline M. canis Bodin 1902 \\
\hline M. gypseum (Bodin) Guiart et Grigorakis 1928 \\
\hline M. nanum Fuentes 1956 \\
\hline Trichophyton Malmsten 1845 \\
\hline T. mentagrophytes (Robin) Blanchard 1895 \\
\hline T. rubrum (Castellani) Sabouraud 1911 \\
\hline T. terrestre Durie \& Frey, 1957 \\
\hline T. ajelloi (Vanbreuseghem, 1952) \\
\hline
\end{tabular}

Table.2 Anamorph-Teleomorph form of Keratinolytic Fungi

\begin{tabular}{|c|c|}
\hline Anamorph & Teleomorph \\
\hline Microsporum, Trichophyton & Arthroderma \\
\hline T. mentagrophytes ${ }^{a}$ & A. benhamiae (Ajello, L., and S. L. Cheng. 1967.) \\
\hline M. gypseum $^{\mathrm{b}}$ & A. gypseum (Stockdale, P. M. 1961. 1963, Weitzman, I., M. R. et al. 1986) \\
\hline M. gypseum $^{\mathrm{b}}$ & A. incurvatum (Stockdale, P. M. 1961. 1963, Weitzman, I., M. R. et al. 1986) \\
\hline M. nanum & $\begin{array}{l}\text { A. obtusum (Dawson, C. O., and J. C. Gentles. 1959, Weitzman, I., M. R. et al. } \\
\text { 1986) }\end{array}$ \\
\hline $\begin{array}{l}\text { M. canis var. canis, M. canis } \\
\text { var. distortum }\end{array}$ & A. otae (Hasegawa, H., and U. Kazuya. 1975., Weitzman, I., M. R. et al. 1986) \\
\hline T. mentagrophytes ${ }^{a}$ & A. vanbreuseghemii (Takashio, M. 1973.) \\
\hline Trichophyton ajelloi & Arthroderma uncinatum (Dawson\&Gentles1961) \\
\hline Trichophyton terrestre & $\begin{array}{l}\text { Arthroderma insingulare, Arthroderma lenticulare, Arthroderma quadrifidum } \\
\text { (Padhye, A.A.; Carmichael, J.W. 1972, , G.C. Tsao \& Plunkett 1965, C.O. } \\
\text { Dawson \& Gentles 1961) }\end{array}$ \\
\hline Chrysosporium keratinophilum & Aphanoascus keratinophilus (Punsola \& Cano 1990) \\
\hline Chrysosporium indicum & (Randhawa, H.S.; Sandhu, R.S. 1964) \\
\hline
\end{tabular}

${ }^{5}$ These anamorph species has more than one teleomorph 
Table.3 Distribution of Keratinophillic Fungi from Different Poultry Sampling Site

\begin{tabular}{|c|c|c|c|c|c|c|c|c|c|c|c|c|}
\hline & \multicolumn{10}{|c|}{ sampling sites } & \multirow[b]{2}{*}{ total } & \multirow[b]{2}{*}{$\begin{array}{l}\% \\
\text { distribution }\end{array}$} \\
\hline & Gajanuru & Soraba & Sagar & Mattur & \begin{tabular}{|l|} 
bhad \\
ravati
\end{tabular} & $\begin{array}{l}\text { Shivamogga } \\
\text { city }\end{array}$ & Shikaripura & $\begin{array}{l}\text { Hosanag } \\
\text { ara }\end{array}$ & Thirthahalli & Holehonnuru & & \\
\hline $\begin{array}{l}\text { Number of samples } \\
\text { examined }\end{array}$ & 30 & 30 & 30 & 30 & 30 & 30 & 30 & 30 & 30 & 30 & 300 & \\
\hline $\begin{array}{l}\text { Number of positive } \\
\text { samples }\end{array}$ & 20 & 17 & 23 & 18 & 26 & 25 & 18 & 21 & 17 & 19 & 204 & \\
\hline$\%$ distribution & 66.66 & 56.66 & 76.66 & 60 & 86.66 & 83.33 & 60 & 70 & 56.66 & 63.33 & 68 & \\
\hline \multicolumn{13}{|l|}{ Fungi recorded } \\
\hline Microsporum gypseum & 02 & 01 & 03 & 01 & 01 & 03 & 01 & 03 & 01 & 01 & 17 & 5.67 \\
\hline Microsporum nanum & 01 & 02 & 02 & 01 & 02 & 01 & 02 & 01 & 03 & 01 & 16 & 5.33 \\
\hline Microsporum canis & 01 & 0 & 01 & 01 & 03 & 01 & 02 & 01 & 02 & 02 & 14 & 4.67 \\
\hline $\begin{array}{l}\text { Chrysosporium } \\
\text { keratinophillum }\end{array}$ & 01 & 01 & 01 & 02 & 01 & 03 & 01 & 03 & 01 & 01 & 15 & 5.00 \\
\hline $\begin{array}{l}\text { Chrysosporium } \\
\text { lobatum }\end{array}$ & 01 & 03 & 02 & 01 & 03 & 02 & 01 & 01 & 03 & 02 & 19 & 6.33 \\
\hline $\begin{array}{l}\text { Chrysosporium } \\
\text { tropicum }\end{array}$ & 01 & 02 & 03 & 02 & 04 & 03 & 02 & 03 & 01 & 01 & 22 & 7.33 \\
\hline $\begin{array}{l}\text { Chrysosporium } \\
\text { indicum }\end{array}$ & 05 & 03 & 04 & 03 & 05 & 05 & 03 & 04 & 02 & 05 & 39 & 13.00 \\
\hline $\begin{array}{l}\text { Epidermophyton } \\
\text { floccosum }\end{array}$ & 01 & 0 & 01 & 02 & 0 & 01 & 0 & 01 & 01 & 01 & 8 & 2.67 \\
\hline $\begin{array}{l}\text { Trichophyton } \\
\text { mentagrophytes }\end{array}$ & 02 & 01 & 02 & 01 & 02 & 02 & 01 & 01 & 01 & 01 & 14 & 4.67 \\
\hline Trichophyton terrestre & 02 & 01 & 02 & 02 & 02 & 01 & 02 & 01 & 01 & 02 & 16 & 5.33 \\
\hline Trichophyton ajelloi & 01 & 02 & 0 & 01 & 01 & 01 & 01 & 01 & 0 & 01 & 9 & 3.00 \\
\hline Trichophyton rubrum & 02 & 01 & 02 & 01 & 02 & 02 & 02 & 01 & 01 & 01 & 15 & 5.00 \\
\hline Total & 20 & 17 & 23 & 18 & 26 & 25 & 18 & 21 & 17 & 20 & 204 & 68.00 \\
\hline
\end{tabular}


Graph.1 Distribution of Individual Keratinolytic Fungi in Different Poultry Sampling Sites

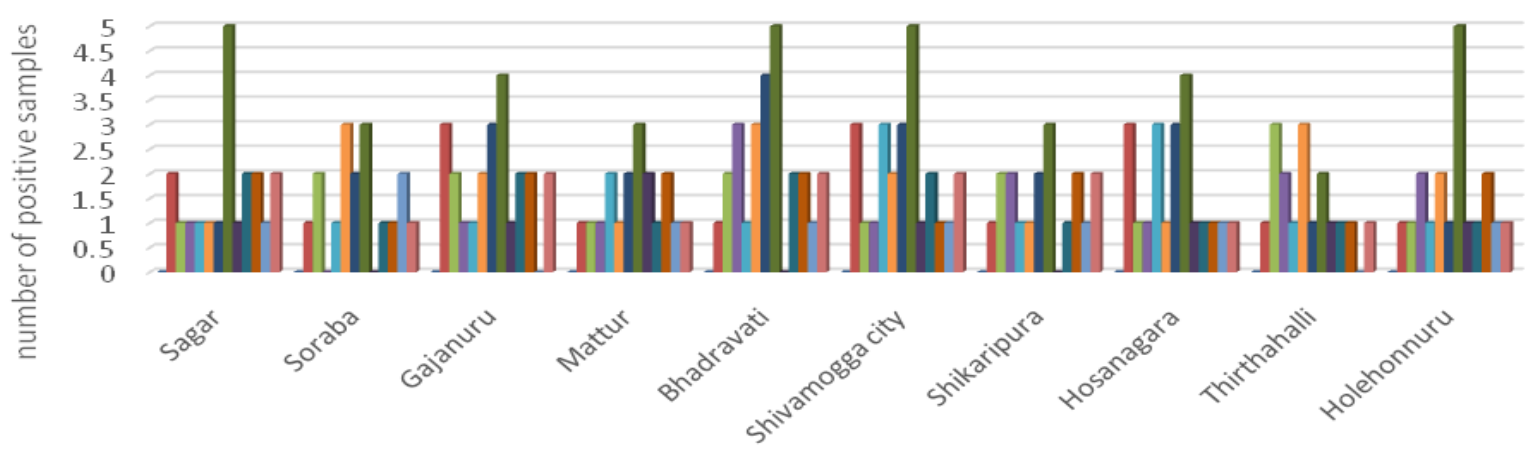

distribution of keratinolytic fungi in different sampling sites

\begin{tabular}{|c|c|c|}
\hline Microsporum gypseum & Microsporum nanum & - Microsporum canis \\
\hline Crysosporium keratinophillum & Chrysosporium lobatum & - Chrysosporium tropicum \\
\hline - Chrysosporium indicum & Epidermophyton floccosum & - Trichophyton mentagrophytes \\
\hline Trichophyton terrestre & Trichophyton ajelloi & Trichophyton rubrum \\
\hline
\end{tabular}

Graph.2 Percentage Distribution of Total Keratinolytic Fungi in Different Poultry Sampling Sites

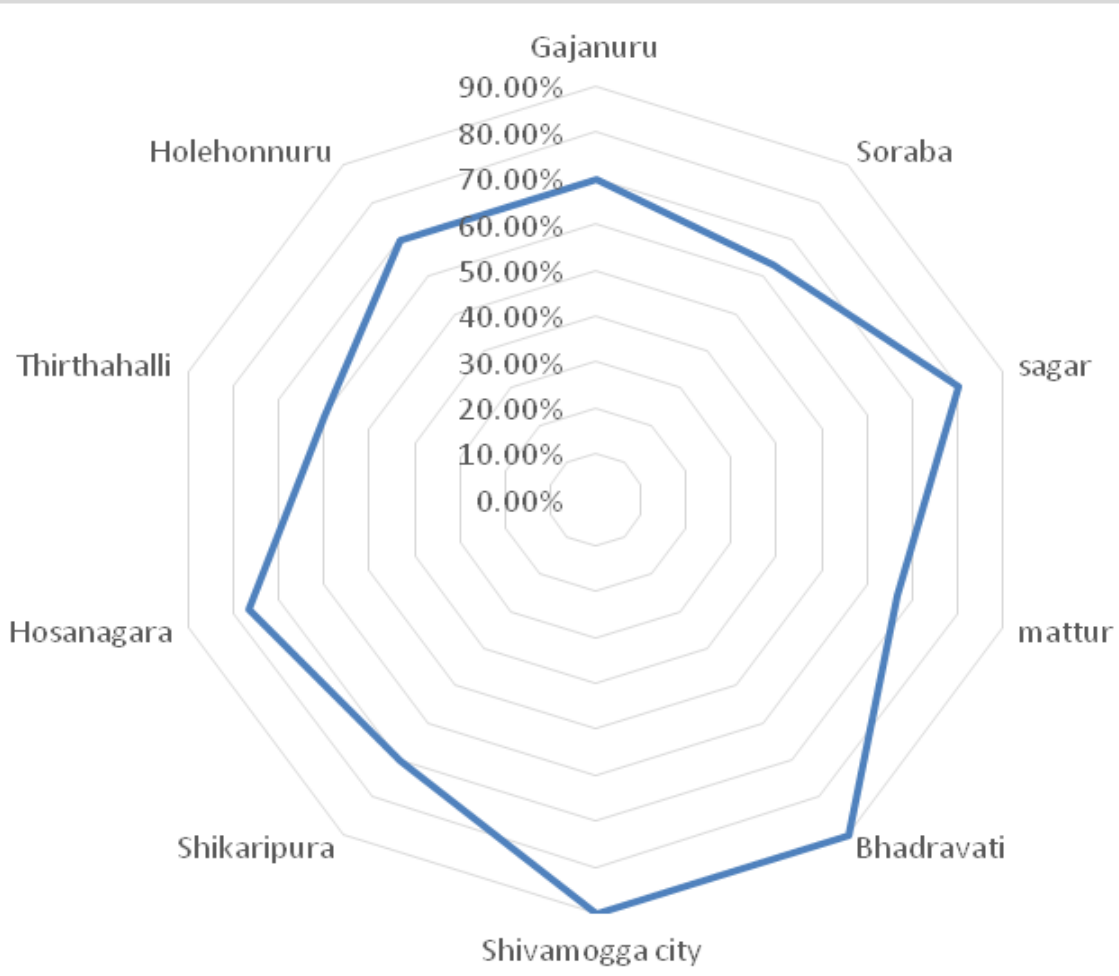


Photographs Showing Culturing of Keratinophillic Fungi using Hair Baiting Technique
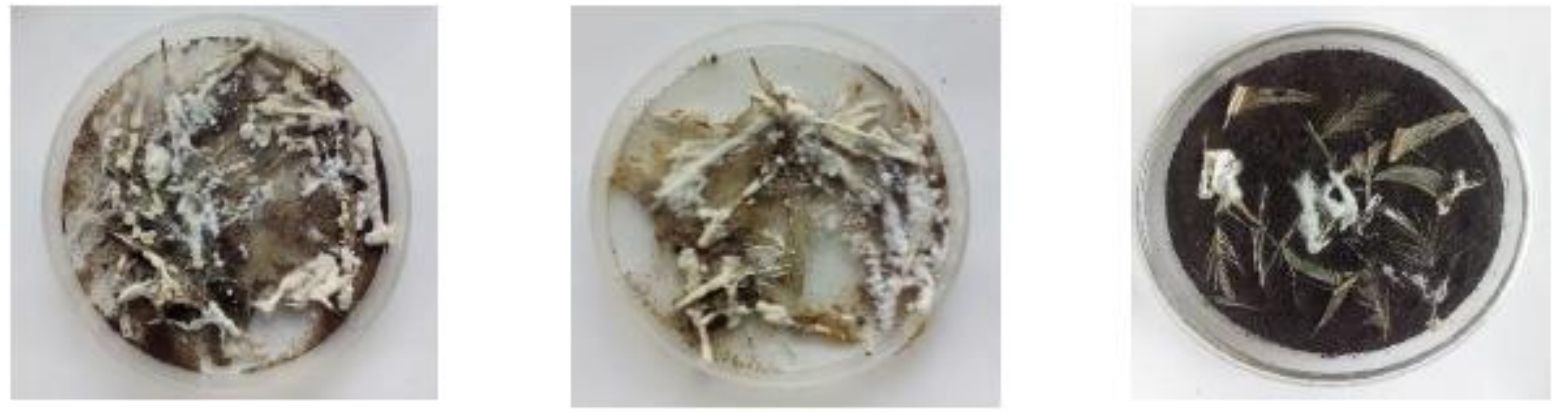

Photographs showing identified pure culture of keratinolytic fungi

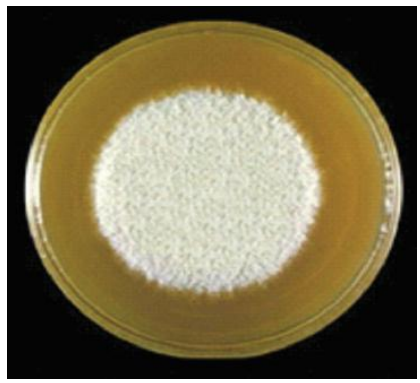

Chrysosporium keratinophillum

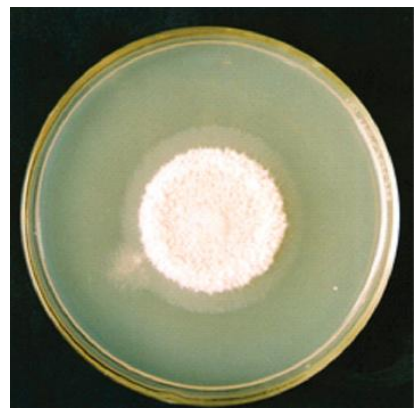

Chrysosporium indicum

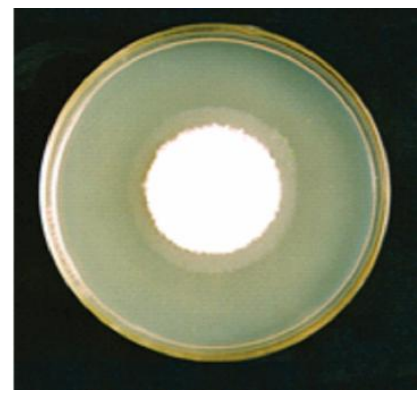

Microsporum gyseum

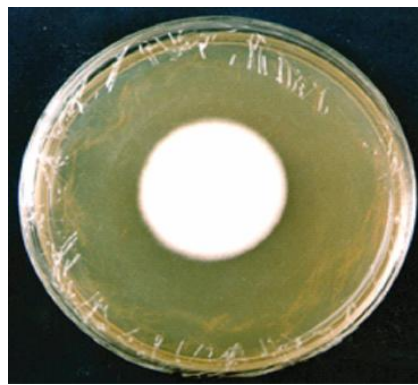

Chrysosporium lobatum

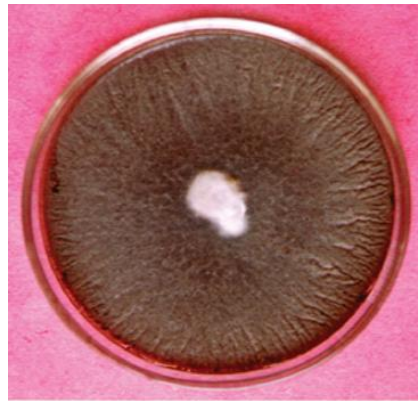

Epidermophyton floccosum

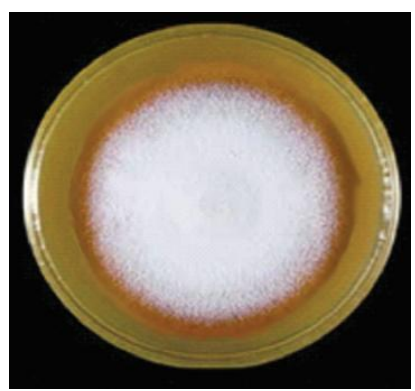

Microsporum nanum

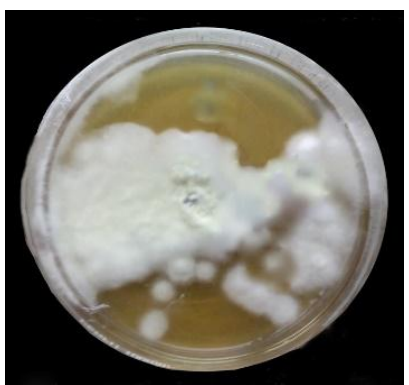

Chrysosporium tropicum

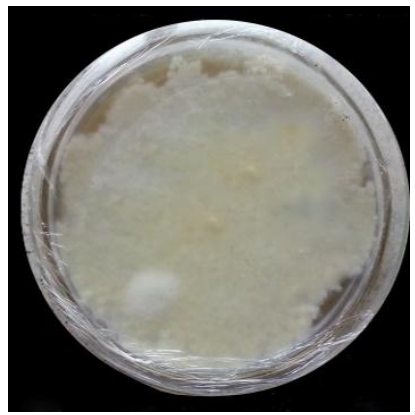

Microsporum canis

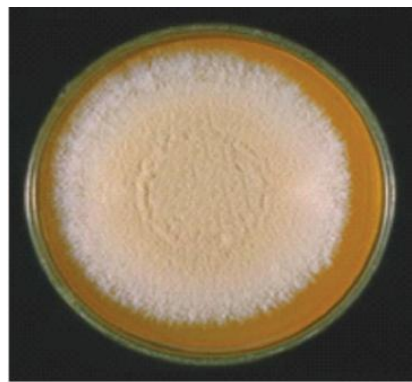

Trichophyton mentagrophytes 


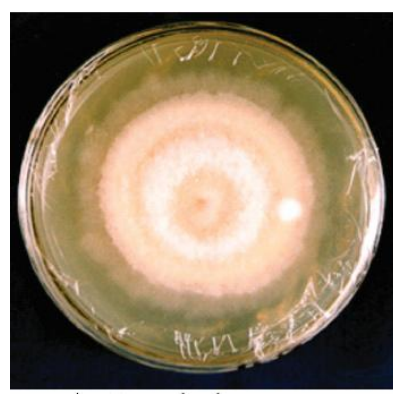

Trichophyton terrestre

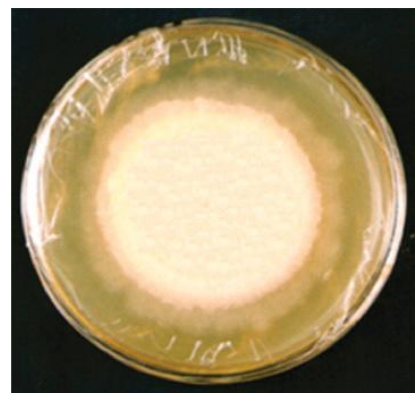

Tricophyton ajelloi

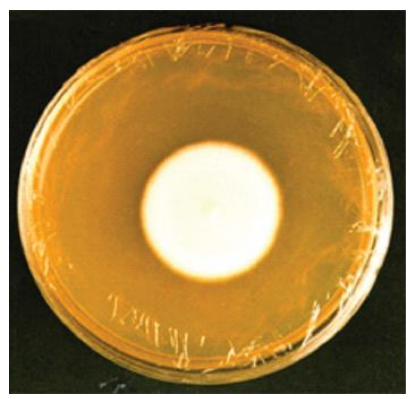

Tricophyton rubrum
Percentage Distribution of Individual Keratinolytic Fungi

Our study also revealed the same, that in all sampling sites, Chrysosporium indicum has highest percentage of distribution of $13.00 \%$, was the most abundant and dominant species in all 10 sampling sites. (Table-1)

Chrysosporium indicum was previously explored by many native researchers and it was the most abundantly found kearatinolytic fungi due to the smart adaptation to the varied climatic conditions in India (Garg AK. 1966; Ramesh VM and Hilda A. 1999; Vidyasagar GM et al, 2005; Deshmukh SK and Verekar SA. 2011),

Not only Chrysosporium indicum, but all the Chrysosporium species viz., Chrysosporium tropicum (7.33\%) Chrysosporium lobatum $(6.33 \%)$ were dominant species in all sampling sites, which reveal that, the genus Chrysosporium has adopted for various climatic conditions in India and they are mainly considered as "Geophilic Dermatophytes". But the species like Crysosporium keratinophillum (5.00\%) showed less percentage distribution may be due to its parasitic nature. (Graph -2)

Microsporum was the next dominant genus in that opportunistic geophilic dermatophytes like Microsporum gypseum (5.67\%), Microsporum nanum (5.33\%) showed moderate distribution among all sampling sites, but, zoophilic dermatophyte like Microsporum canis (4.67\%), showed least distribution.

Trichophyton genus is third dominant in all sampling sites, in which, geophilic nonpathogenic fungi like Trichophyton terrestre $(5.33 \%)$ and anthropophilic dermatophyte like Trichophyton rubrum $(5.00 \%)$ that is the most common cause of athlete's foot, jock itch and ringworm, were moderately distributed and opportunistic pathogenic fungi like Trichophyton mentagrophytes $(4.67 \%)$ and geophilic fungus like Trichophyton ajelloi (3.00\%) were least distributed.

From genus Epidermophyton we are able to isolated only one species Epidermophyton floccosum (2.67\%), an anthropophilic dermatophyte with a world-wide distribution which often causes tinea pedis, tinea cruris, tinea corporis and onychomycosis, showed least distribution among all the genus isolated, this may be due to its parasitic habitat.

Distribution of keratinolytic fungi in 10 sampling sites was not uniform (Table 1) this may be due to the presence of organic matter present in that soil. The presence organic matter is one of the major factors affecting the presence of keratinolytic fungi in soil (Chmel, L et al, 1972). 
The Present study concludes that, Chrysosporium indicum (13.00\%) was the most dominant species in all 10 sampling sites, may be due to its wide range of adaptation for worm climatic conditions of India.

Among the poultry waste sampling sites Shivamogga city and Bhadravathi town showed highest percentage distribution.

The environmental and edaphic factors is very crucial for distribution of keratinolytic fungi like, Energy resource (keratin), Soil $\mathrm{pH}$, Humidity, Temperature, Geographical location and also Density of human population.

\section{Acknowledgement}

The authors are thankful to the Department of Applied Botany, Kuvempu University, Shivamogga, Karnataka for providing necessary laboratory facilities and thankful to Department of Science and Technology, New Delhi (DST-SERB: SB/EMEQ091/2013 Dated: 04.10.13) for providing financial support through granting research project.

\section{References}

Abdullah, S.K and Hassan, D.A. (1995). Isolation of dermatophytes and other keratinolytic fungi from surface sediments of the Shatt Al-Arab river and its creeks at Basrah, Iraq,Mycoses.,38: 34,163-166.

Ajello, L., and S. L. Cheng. 1967. The perfect state of Trichophyton mentagrophytes. Sabouraudia 5:230 \pm 234 .

Allender, M.C., Dreslik, M., Wylie, S., Phillips, C., Wylie, D.B., Maddox, C., Delaney, M.A. and Kinsel, M.J. (2011). Chrysosporium sp - Infection in Eastern Massasauga Rattlesnakes. Emerging Infectious Diseases, 17(12): 2383-2384.
Anbu, P., Hilda, A. and Gopinath, S.C. (2004). Fungi of poultry farm and feather dumping soil in Tami Nadu, India. Mycopathologia, 158(3): 303-909.

Bodin, E. 1902. Les champignons parasites de l'homme. 137.

Bouchard, C.J. 1895. Traité de Pathologie Générale. 2:1-932.

Cano, J and Guarro, J. (1990). The genus Aphanoascus. Mycol.Res.94; 355-377.

Cano, J.; Guarro, J. 1990. The genus Aphanoascus. Mycological Research. 94:355-377.

Carmichael, J.W. 1962. Chrysosporium and some other aleuriosporic Hyphomycetes. Canadian Journal of Botany. 40(8):11371173.

Chmel, L., Hasilikowa, A., Hraslo, J and Valclikova, A. (1972). The influence of some ecological factors on keratinolytic fungi in soil, Sabouraudia., 10: 26-36.

Corda, A.C.J. 1833. Deutschlands Flora, Abt. III. Die Pilze Deutschlands. 3-13:65-96.

Dawson, C. O., and J. C. Gentles. 1959. Perfect state of Keratinomyces ajelloi, Nature (London) 183:1345 \pm 1346.

Dawson, C.O.; Gentles, J.C. 1961. The perfect states of Keratinomyces ajelloi Vanbreuseghem, Trichophyton terrestre (Durie): Frey and Microsporum nanum Fuentes. Sabouraudia. 1:49-57.

Dawson, C.O.; Gentles, J.C. 1961. The perfect states of Keratinomyces ajelloi Vanbreuseghem, Trichophyton terrestre (Durie): Frey and Microsporum nanum Fuentes. Sabouraudia. 1:49-57.

Deshmukh, S.K and Verekar, S.A. (2006). The occurrence of dermatophytes and other keratinolytic fungi from the soils of Himachal Pradesh (India). Czech Mycol., 58(1-2): 117-124.

Deshmukh, S.K and Verekar, S.A. (2011). Prevalence of keratinolytic fungi in usar soils of Uttar Pradesh, India. Microbiology Research., 2:e15.

Deshmukh, S.K. (1999). Keratinolytic fungi isolated from soils of Mumbai, India. Mycopathologia., 146: 115-116. 
Deshmukh, S.K. (2002). Incidence of Keratinolytic fungi from selected soils of Kerala state (India). Mycopathol., 156:117-81.

Deshmukh, S.K. (2004). Isolation of dermatophytes and other keratinolytic fungi from the vicinity of salt pan soils of Mumbai (India). Mycopathol., 157:265-7.

Deshmukh, S.K., and Agarwal, S.C and Jain, P.C. (2000). Isolation of dermatophytes and other keratinolytic fungi from soils of Mysore (India). Mycoses., 43: 55-57.

Deshmukh, S.K., and Agarwal, S.C. (1985). Isolation of dermatophytes and other kerationphilic fungi from soils of musoorie (India). Mykosen., 28:98-101.

Durie, E.B.; Frey, D. 1957. A new species of Trichophyton from New South Wales. Mycologia. 49(3):401-411.

Forbes, B.A., Sahm, D.F and Weissfeld, A.S, (2002). Laboratory methods in basic mycology. In: Baileys and Scotts Diagnostic Microbiology,Mosby United States of America., 11: 747-754.

Frey, D., Oldfield R. J and Bridger R. C. (1979). A colour atlas of pathogenic fungi. Wolf medical publication Ltd.

Fuentes, C.A. 1956. A new species of Microsporum. Mycologia. 48(4):613614.

Garetta, G and Piontelli, E.(1975).Isolation of keratinolytic fungi from soil Pavia Italy, Sabouraudia., 13, 33-37.

Garg, A.K.(1996). Isolation of dermatophytes and other keratinolytic fungi from the soils in India, Sabouraudia., 4: 259-265.

Ghosh, G.R and Bhatt, S. (2000). Keratinolytic fungi from Chilka Lakeside soil Orissa (India). Ind J Microbiol., 40:247-54.

Gruby, C. R. 1843. In: C. r. hebd. Séanc. Acad. Sci. (Paris) 17:301-303.

Guiart, J.; Grigoraki, L. 1928. Les champignons parasites de l'homme: Lyon Médical. 141:369-378.

Hasegawa, H., and U. Kazuya. 1975. Nannizzia otae sp. nov., the perfect state of Microsporum canis Bodin. Jpn. J. Med. Mycol. 16:148 \pm 153 .

Hedayati, M.T and Mirzakhani, M. (2009). Survey of keratinolytic fungi in sewage sludge from waste water treatment plants of Mazandaran, Islamic Republic of Iran" Eastern Mediterranean Health Journal., 15(2):451-454.

http://www.academia.edu/4630861/Monograp h_On_Dermatophytes_A_guide_for_isol ation_and_identification_of_dermatophy tes_diseases_and_treatment_By_Moham ed_Refai_Heidy_Abo_El-

Yazid_and_Mahmoud_El-Hariri.

http://www.provlab.ab.ca/mycol/tutorials/der m/dermwho.htm .

http://www.shimoga.nic.in/stats.htm, District Statistics Booklet (PDF), Indicators Regarding Agriculture and Allied 201213, Fertilizer (NPK) consumption in Kilogram per Hectare, page number 242.

Kachuei, R., Emami, M., Naeimi, B and Diba, K. (2012). Isolation of keratinolytic fungi from soil in Isfahan province, Iran. Journal de Mycologie Medicale., 22(1):8-13.

Khanam, S.J.P and Jain, P.C. (2002). Isolation of keratin degrading fungi from soil of damoh

(India)

Asian.J.Microbiol.Biotech.Environ.Sci., 42:102-110.

Kim, J.D. (2003). Keratinolytic Activity Of Five Aspergillus Species Isolated From Poultry Farming Soil In Korea. Mycobiology., 31(3): 157-161.

Kumar, R., Mishra, R., Maurya, S and Sahu, H. B. (2013). Isolation and identification of keratinolytic fungi from garbage waste soils of Jharkhand region of India. European Journal of Experimental Biology., 3(3):600-604.

Langeron \& Miloch., (1930) Annls Parasit. hum. comp.8: 495

Majchrowicz, I., Dominik, T. (1969). Further contribution to the knowledge of keratinolytic and keratinophilic soil fungi in the region of Szczecin. Keratinolytic and keratinophilic fungi in 
the immediate surroundings of cattle. Ekol. Pol. 17, 87.

Malmsten PH. 1845. Trichophyton tonsurans, harskarandemogel. Bidrag till utredande af de sjukdomar, som vallaharets affall. Stockholm: L.J. Hjerta.

Marchisio, V.F., Curetti, D., Cassinelli, C and Bordese, C. (1991). Keratinolytic and keratinolytic fungi in the soils of Papua New Guinea. Mycopathologia., 115(2): 113-119.

Marchisio, V.F., Preve, L and Tullio, V. (1996). Fungi responsible for skin mycoses in Turin (Italy). Mycoses., 39 (3-4):141-150.

McGinnis, M.R. (1980). Laboratory Handbook of Medical Mycology. Academic Press, London, UK.

Moallaei, H., Zaini, F., Pihet, M., Mahmoudi, $\mathrm{M}$ and Hashemi, J. (2006). Isolation of keratinolytic fungi from soil samples of forests and farm yards. Iranian Journal of Public Health., 35(4):62-69.

Monod, M., Jaccoud, S., Zaugg, C., Lechenn, B., Baudraz, F and Panizzon, R. (2002). Survey of Dermatophyte Infections in the Lauseanne Area (Switzerland). Dermatology., 205: 201-203.

Pakshir, K and Hashemi, J. (2006). Dermatophytosis in Karaj, Iran. Indian Journal of Dermatology., 51(4):262264.

Pàlsson, G. (1968). Geophilic dermatophytes in the soil in Sweden- Studies on their occurrence and pathogenic properties, Acta Veterinaria Scandinavica., 25:189.

Papini, R., Mancianti, F., Grassotti, G and Cardini, G. (1998). Survey of keratinolytic fungi isolated from city park soils of Pisa, Italy. Mycopathologia., 143, (1):17-23.

Pore, R.S.; Tsao, G.C.; Plunkett, O.A. 1965. A new species of Arthroderma established according to biological species concepts. Mycologia. 57:969-973.

Ramesh, V.M and Hilda, A. (1999). Incidence of keratinolytic fungi in the soil of primary schools and public parks of
Madras City India. Mycopathol., 143:139-45.

Randhawa, H.S.; Sandhu, R.S. 1964. Keratinophyton terreum gen.nov., sp.nov., a keratinophilic fungus from soil in India. Sabouraudia. 3(3):251-256.

Rebell, G. and Taplin, D. (1970). The Dermatophytes. 2nd Revised ed., University of Miami Press, Coral Gables, Florida. USA.

Rebell, G. and Taplin, D. (1974). Dermatophytes. Their recognition and ident!fication. Coral Gables,Florida: University of MiamiPress.

Refai, M., El-Yazid, H.A and El-Hariri, M. (2013) Monograph on dermatophytes: A guide for isolation and identification of dermatophytes, diseases and treatment. Department of Microbiology, Faculty of Veterinary Medicine, Cairo University.

Rippon, J.W. 1988. Medical Mycology. The Pathogenic Fungi and the Pathogenic Actinomycetes. (3rd edn.), W. B. Saunders, Philadelphia.

Sabouraud 1911, Trichophyton rubrum (Castell.) Sabour., British Journal of Dermatology: 389 (1911).

Sabouraud R. Les teignes. Paris: Masson \& Co. $1^{\text {st }}$ edit; 1907.

Saha, S. (2013). Exploration of keratinolytic actinobacteria for the bioconversion of poultry feather waste into poultry feed supplement. Phd thesis. Shodhganga. Page 2(Introduction).

Scharapov, V.M. 1978. Species Chrysosporii Cda. novae. Novosti Sistematiki Nizshikh Rastenii. 15:141-149.

Sharma, M and Sharma, M. (2010). Incidence of dermatophytes and other keratinolytic fungi in the schools and college playground soils of Jaipur, India. Afr $J$ Microbiol Res., 4:2647-54.

Sharma, R and Rajak, RC. (2003). Keratinolytic Fungi: Nature's Keratin Degrading Machines. Resonance, 28-40.

Sharma, R and Swati. (2012). Effect of keratin substrates on the growth of keratinolytic fungi. J. Acad. Indus., 1 (4). 
Sparks and Donald (2003). Environmental Soil Chemistry. Academic Press, London, UK.

Spiewak, R and Szostak, W. (2000). Zoophilic and Geophilic dermatophytoses among farmers and non-farmers in eastern Poland. Annals of Agricultural and Environmental Medicine., 7(2):125-129.

Stockdale, P. M. 1961. Nannizzia incurvata gen. nov., sp. nov., a perfect state of Microsporum gypseum (Bodin) Guiart et Grigorakis. Sabouraudia 1:41 \pm 48 .

Stockdale, P. M. 1963. The Microsporum gypseum complex (Nannizzia incurvata Stockd., N. gypsea (Nann) comb. nov., N. fulva sp. nov.) Sabouraudia $3: 114 \pm 126$.

Takashio, M. 1973. Une nouvelle forme sexueÂe du complex Trichophyton mentagrophytes, Arthroderma vanbreuseghemii sp. nov. Ann. Parasitol. 48: $713 \pm 732$.

Van Oorschot, C.A.N. (1980). A reverse of crysoporium and allied genera. CBS, Baarn Netherlands. Stud. Mycol., 20: 189.

Vanbreuseghem, R. (1952). Keratin digestion by dermatophytes: a specific diagnostic method. Mycologia., 44: 176-182.

Vanbreuseghem, R. (1952). Technique biologique pour 1'isolement des dermatophytes du sol (Biological technique for isolating dermatophytes from soil). Ann. Soc. Belge. Med. Trop., 32: 173-178.

Vidyasagar, G.M., Hosmani, $\mathrm{N}$ and Shivkumar, D. (2005). Keratinolytic fungi isolated from hospital dust and soils of public places at Gulbarga, India. Mycopathol., 159:13-21.

Vogt, H. and Stute, K. (1975). Sceinbare Aminoäureverdaulichkeitdes federmehls beiLegehennen. Arch. Gaflügelkd, 39:51-53.

Volz, P.A., Wlosinski, M.J and Wasser, S.P. 1991.Sparse diversity of potential pathogenic soil micro-fungi in the Ukraine" Microbios., 65:264-265,187193.

Weitzman, I., M. R. McGinnis, A. A. Padhye, and L. Ajello. 1986. The genus Arthroderma and its later synonym Nannizzia. Mycotaxon 25:505 \pm 518 .

Ziegler, H. (1966). Vergleichende Untersuchungen über den Stoffwechsel von Schimmelpilzen und Dermatophyten. Z Allg Mikrobiol., 6: 74-85.

\section{How to cite this article:}

Ashwathanarayana, R., and Raja naika. 2016. Prevalence of Keratinolytic Fungi Isolated from the Poultry waste sites around Shivamogga City, Karnataka, India. Int.J.Curr.Microbiol.App.Sci. 5(2): 344-358. doi: http://dx.doi.org/10.20546/ijcmas.2016.502.040 